Virginia Commonwealth University

vCU Scholars Compass

Periodontics Publications

Dept. of Periodontics

2001

\title{
Factors considered by new faculty in their decision to choose careers in academic dentistry
}

Harvey A. Schenkein

Virginia Commonwealth University

Al M. Best

Virginia Commonwealth University, albest@vcu.edu

Follow this and additional works at: http://scholarscompass.vcu.edu/peri_pubs

Part of the Periodontics and Periodontology Commons

Reprinted by permission of Journal of Dental Education, Volume 65, 9 (September 2001). Copyright 2001 by the American Dental Education Association.

\section{Downloaded from}

http://scholarscompass.vcu.edu/peri_pubs/10

This Article is brought to you for free and open access by the Dept. of Periodontics at VCU Scholars Compass. It has been accepted for inclusion in Periodontics Publications by an authorized administrator of VCU Scholars Compass. For more information, please contact libcompass@vcu.edu. 


\title{
Factors Considered by New Faculty in Their Decision to Choose Careers in Academic Dentistry
}

\author{
Harvey A. Schenkein, D.D.S., Ph.D.; Al M. Best, Ph.D. \\ Abstract: To determine the characteristics of new dental faculty and what factors influenced them to choose academic careers, a \\ survey was sent to deans at all U.S. dental schools to be distributed to faculty with length of service of four years or less. \\ Responses were received from 240 individuals. About half of the respondents had been in private practice for an average of eight \\ years, and 20 percent had military experience averaging almost sixteen years. A majority had postgraduate training and 60 \\ percent had specialty training. Nearly 32 percent of new faculty were female and 80 percent were U.S. citizens. Analyses of \\ responses to survey items indicated that correlated factors in the survey fell into the following empirical categories: teaching and \\ scholarship, income and indebtedness, research, work schedule, influence of mentors and role models, and long-term aspirations. \\ In general, the respondents identified factors relating to teaching and scholarship to be the most important influences on their \\ choice of academic careers, while concerns about income and indebtedness were the most important negative considerations in \\ this regard. Other positive factors identified by the survey related to the influence of mentors and role models, long-term \\ aspirations, and research. Age, private practice experience, and military experience were found to particularly influence the new \\ faculty members' responses to items concerning income and indebtedness, and citizenship influenced responses to factors \\ relating to research. The data from this select group of dentists support the current view that inequities in income of dental faculty \\ compared to private practitioners and student debt are important concerns in choosing academic careers. Importantly, the desire to \\ teach and participate in scholarly activities are important attractions in academic careers. Mentoring activities and creation of \\ opportunities for career development are crucial factors in developing interest in academics among graduate dentists.
}

Dr. Schenkein is the Paul Tucker Goad Professor and Assistant Dean for Research and Dr. Best is Associate Professor of Biostatistics, both at the Virginia Commonwealth University School of Dentistry. Direct correspondence and requests for reprints to Dr. Harvey A. Schenkein, Clinical Research Center for Periodontal Disease, Virginia Commonwealth University, School of Dentistry, P.O. Box 980566, 521 N. 11th Street, Richmond, VA 23298; 804-828-9185 phone; 804-828-5787 fax; hschenke@hsc.vcu.edu.

Key words: dentistry, academic careers, faculty

Submitted for publication 1/24/01; accepted 6/27/01

$\mathrm{T}$ The recent Report of the AADS President's Task Force on Future Dental School Faculty ${ }^{1}$ concluded that dental education faces a shortage of faculty that is reaching crisis proportions. Recent data indicate that a significant proportion of dental school faculty is over fifty years old and that departures of faculty from retirements alone will leave faculty ranks significantly depleted during the next decade. Furthermore, it was the task force's view that little is being done within dental education to encourage young dentists to consider academic careers. Recently, Haden and colleagues ${ }^{2}$ surveyed U.S. dental school deans to determine the magnitude of this human resource crisis, their perceived reasons for its occurrence, and the strategies being employed to address the problem. The authors estimated that nearly 300 vacant positions existed at forty-five dental schools and that separations of full-time dental faculty were mainly due to retirement or faculty opt- ing for private practice careers. Furthermore, the major impediments to recruitment of new faculty were reported to be lack of competitive salaries and inadequate credentials in the form of clinical or research training.

Although the magnitude of the "faculty problem" has been documented, ${ }^{2}$ there is only speculation as to the reasons for the decreased interest in young dentists to consider academic careers. However, some well-documented factors, including the magnitude of student debt and comparisons of income of dental faculty and dental practitioners, appear to be influential. A number of other factors thought to be considered by young dentists when choosing career paths were delineated by the task force, resulting in five recommendations for recruitment, development, and retention of dental faculty.

We hypothesized that we can learn a great deal about motivating factors that would lead to a choice 
of academic dental careers from new faculty who chose academics. To this end, a survey instrument was developed that identified thirty-seven possible factors that may be considered by dentists or dental students who are considering an academic position. Respondents were asked to rate the importance of each factor in making this decision, and say whether the factor was considered to be a positive or negative influence on the decision.

\section{Methods}

\section{Survey Instrument}

A survey was prepared that identified thirtyseven factors that new faculty may have considered to be important in leading to their decision to enter academic dentistry. This survey was mailed to the deans of all U.S. dental schools, with a request that they distribute the survey to all dental faculty with D.D.S./D.M.D. degrees (or their equivalent) having full-time appointments (four or more days per week) at the school of dentistry, but with length of service as full-time faculty in dental education of four years or less. Respondents were asked to do the following:

1. Rate each factor on a scale of 1-5 as being important in making the decision to enter academics (1) or unimportant and not a consideration (5).

2. For each item, indicate whether they considered the factor a positive influence on their decision to enter academics $(\mathrm{P})$ or a negative influence $(\mathrm{N})$.

Additionally, respondents were asked to respond to the following items to provide demographic data:

1. How many years ago did you become a fulltime dental faculty member?

2 . If you were in private practice prior to becoming a faculty member, for how many years did you practice?

3. If you were in the military prior to becoming a faculty member, for how many years?

4. How many years of postgraduate training (including specialty and research) have you had?

5. If you are a specialist, what is your specialty area?

6. From which dental school did you graduate?

7. Are you in a tenure-track position?

8. Sex
9. Age
10. Citizenship
11. Dental school

\section{Data Analyses}

Demographic data are depicted using descriptive statistics. For the thirty-seven individual factors in the survey, the responses were converted to a continuous scale so that the strongest positive factor (that is, a response of $[1, \mathrm{P}]$ ) was given a value of +4 , the strongest negative factor (that is, a response of [1, $\mathrm{N}]$ was given a value of -4 , and every response of 5 $[\mathrm{N}$ or $\mathrm{P}]$ was given a value of 0 . Mean values were calculated for these values and they constituted the unit of analysis for the survey responses.

The correlations between thirty-seven items in the survey were analyzed using principal component analysis. Six factors were sufficient to account for more than 50 percent of the covariance. These six factors were rotated using varimax and the factor pattern inspected for interpretability. Six scores, one for each factor, were derived by averaging the preferences of items corresponding to that factor.

Analysis of covariance (ANCOVA) was used to explore the relationship between demographic variables and the survey item scores.

Additionally, two analyses were performed. One analysis used only the faculty members with one year or less of experience looking at the above variables as predictors. The second analysis used all respondents and included interaction terms to test whether the relationships with the above predictors were different, depending upon whether the faculty member reported $\leq 1$ year of full-time service or one to four years of full-time service. The division of the data set in this manner divided the sample approximately in half and permitted separate analyses of results for the most recently appointed faculty. This additional analysis was done to determine if the responses of faculty with more than one year of service were influenced by their experiences in academics, thus reflecting their current attitudes rather than considerations prior to entering academics. Since faculty with up to four years of service were surveyed, it is possible that the number of years in academics could alter the respondents' perceptions of the factors motivating their choice of a career in academic dentistry. 


\section{Results}

\section{Characteristics of New Faculty}

The sample of faculty included only those with dental degrees (D.D.S., D.M.D., or equivalent) with four years or less full-time service in academic dentistry. Responses were received from 240 individuals. Not all deans reported the number of surveys distributed at their schools, so the underlying sample and response rate could not be calculated.

As seen in Table 1, about 30 percent of new faculty were female, and about 80 percent were U.S. citizens. About 50 percent of new faculty were appointed in tenure-track positions. More than half of the respondents (55.5 percent) reported that they had 0-1 year of service. The age distribution, which is shown in Figure 1, demonstrates that about half of the respondents were over age forty.

\begin{tabular}{|c|c|c|c|}
\hline Characteristic & Percent & $\begin{array}{l}\text { Range } \\
\text { (years) }\end{array}$ & $\begin{array}{c}\text { Mean } \\
\text { years } \pm \text { SD }\end{array}$ \\
\hline $\begin{array}{l}\text { Faculty previously in } \\
\text { private practice }\end{array}$ & 54.3 & $1-35$ & $8.14 \pm 7.43$ \\
\hline $\begin{array}{l}\text { Faculty with previous } \\
\text { military experience }\end{array}$ & 20.4 & $1-28$ & $15.92 \pm 8.83$ \\
\hline $\begin{array}{l}\text { Faculty with postgraduate } \\
\text { training }\end{array}$ & 87.0 & $1-13$ & $3.98 \pm 2.51$ \\
\hline $\begin{array}{l}\text { Faculty with specialty } \\
\text { training }\end{array}$ & 59.5 & & \\
\hline $\begin{array}{l}\text { Faculty in tenure-track } \\
\text { positions }\end{array}$ & 52.9 & & \\
\hline Percent female & 31.7 & & \\
\hline U.S. citizenship & 80.3 & & \\
\hline \multicolumn{4}{|l|}{$\begin{array}{l}\text { Years of full-time faculty } \\
\text { service: }\end{array}$} \\
\hline 0 & 22.7 & & \\
\hline 1 & 32.8 & & \\
\hline 2 & 19.8 & & \\
\hline 3 & 17.0 & & \\
\hline 4 & 7.7 & & \\
\hline
\end{tabular}

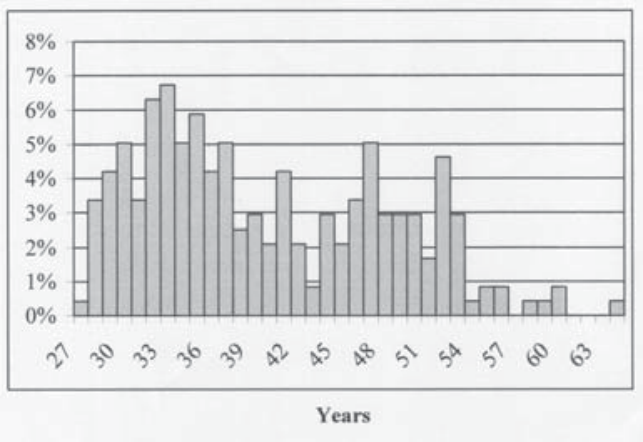

Figure 1. Age distribution of new dental faculty
With regard to previous career and educational experiences, about half of the new faculty reported that they had some previous private practice experience, while about 20 percent had military experience. Advanced educational training was reported by the majority of new faculty: 87 percent had formal postgraduate training, and 59.5 percent had received specialty training. The distribution of new faculty who were specialists is shown in Table 2.

\section{Principal Component Analyses of Survey Items}

To first determine if the responses to groups of survey items were correlated, the thirty-seven items in the survey were analyzed using factor analysis. Six factors were sufficient to account for 51.7 percent of the covariance. It was found that the correlated items could be assigned to empirical categories that roughly described the items within the category. These categories were:

- Teaching and scholarship items

- Income and indebtedness items

- Research items

- Work schedule items

- Influence of mentors and role models items

- Long-term aspirations items

The survey items that correlated to these categories are shown in Table 3.

\section{Survey Results}

The survey results for all respondents are shown in Table 4. Results could range from +4 (an impor-

\begin{tabular}{lcc} 
Table 2. Characteristics of new dental faculty: \\
specialty areas \\
Specialty Areas of New Faculty & $\mathrm{n}$ & $\%$ \\
\hline Prosthodontics & 35 & 23.8 \\
Periodontics & 26 & 17.7 \\
OMFS & 18 & 12.2 \\
Pediatric Dentistry & 15 & 10.2 \\
Orthodontics & 14 & 9.5 \\
Endodontics & 10 & 6.8 \\
Dental Public Health & 8 & 5.4 \\
Oral Pathology & 8 & 5.4 \\
OMF Radiology & 5 & 3.4 \\
Anesthesiology & 2 & 1.4 \\
Maxillofacial Prosthetics & 2 & 1.4 \\
Pediatric/Orthodontics & 1 & 0.7 \\
Pediatric/Dental Anesthesiology & 1 & 0.7 \\
Prosthodontics/Pediatric & 1 & 0.7 \\
Prosthodontics/Public Health & 1 & 0.7 \\
\hline
\end{tabular}


Table 3. Correlated items as determined by principal components analysis

\begin{tabular}{lc} 
Teaching and scholarship items: & $\begin{array}{c}\text { Factor } \\
\text { Loading }\end{array}$ \\
\hline $\begin{array}{l}\text { Opportunity for regular interaction with other } \\
\text { faculty dentists }\end{array}$ & 0.44 \\
University collegial environment & 0.54 \\
Variety of work activities available in academics & 0.64 \\
Desire to be a teacher & 0.64 \\
Interest in science, new discovery, exploration & 0.72 \\
Opportunity to always be on cutting edge & 0.72 \\
Intellectual challenges and stimulation & 0.84 \\
Opportunity to influence a field of study and & 0.69 \\
$\quad$ shape a profession & \\
Varied life and professional activities & 0.70 \\
Income and indebtedness items: & \\
\hline $\begin{array}{l}\text { Income level of dental faculty } \\
\text { Pressure to generate income for university }\end{array}$ & 0.69 \\
Time required for preparation for academic career & 0.67 \\
Income differential compared to private practice & 0.62 \\
Change by universities to an emphasis on & 0.81 \\
$\quad$ non-tenure-track positions & 0.54 \\
Level of indebtedness &
\end{tabular}

Research items:

\begin{tabular}{|c|c|}
\hline Opportunity to do research & 0.84 \\
\hline Obligation to do research & 0.50 \\
\hline $\begin{array}{l}\text { Opportunity to collaborate on projects of national } \\
\text { and international importance }\end{array}$ & 0.57 \\
\hline Research training opportunities & 0.72 \\
\hline Research training experiences & 0.76 \\
\hline \multicolumn{2}{|l|}{ Work schedule items: } \\
\hline Work schedule of dental faculty & 0.45 \\
\hline Desir & 0.48 \\
\hline s in privat & 0.65 \\
\hline Perceptions of private practice & 0.60 \\
\hline \multicolumn{2}{|l|}{ Influence of mentors and role models items: } \\
\hline $\begin{array}{l}\text { Faculty role model at your dental school/ } \\
\text { advanced education program }\end{array}$ & 0.66 \\
\hline Influence of faculty mentor & 0.61 \\
\hline Experiences during advanced training & 0.73 \\
\hline \multicolumn{2}{|l|}{ Long term aspirations items: } \\
\hline $\begin{array}{l}\text { Opportunity for interaction with university/ } \\
\text { medical center faculty }\end{array}$ & 0.52 \\
\hline $\begin{array}{l}\text { Chance to develop a national/international } \\
\text { network of colleagues and friends }\end{array}$ & 0.50 \\
\hline $\begin{array}{l}\text { Aspirations to be a dental school or university } \\
\text { administrator }\end{array}$ & 0.62 \\
\hline Freedom of movement & 0.49 \\
\hline Success in dental school & 0.53 \\
\hline Access to the tenure system & 0.67 \\
\hline
\end{tabular}

Opportunities for advancement

Influence of parents and relatives

Convenience

Military service experiences

Factor loading after extraction of principal components and varimax rotation.

Six factors accounted for 51.7 percent of the covariance between the items. tant consideration that was a positive influence) to 4 (an important consideration that was a negative influence), while scores close to 0 indicated factors that were not important considerations. Scores are obviously skewed toward positive factors because the respondents were selected as a consequence of choosing an academic career.

The nine items with the highest scores (factors that were important positive considerations in choosing academic careers) were all teaching and scholarship items identified by factor analysis as being correlated. In contrast, the items with the lowest scores (factors that were important but negative considerations in choosing academic careers) were all correlated items termed income and indebtedness items. Other categories of responses that were relatively strong positive considerations were items related to the influence of mentors and role models, long-term aspirations, and research.

\section{Relationships Between Demographic Variables and Responses to Individual Survey Items}

The influence of demographic variables on the survey results were examined using stepwise analysis. The results are shown in Table 5. Although there were isolated instances of relationships of individual responses to these variables, those items categorized as income and indebtedness items frequently appeared in this analysis. These responses were influenced by the respondents' age and previous professional experience. For new faculty with fewer years of private practice experience and for those with fewer years of military experience, factors related to income and indebtedness were a negative consideration compared to faculty with more extensive experience. For example, since there is a positive correlation between "years in private practice" and "level of indebtedness," those new faculty with fewer years in practice viewed indebtedness as a more negative influence on the decision to enter academics. Considerations of importance for younger new faculty were income differential compared to private practice, the time needed for preparation for academic careers, and the intellectual aspects of academics. 


\begin{tabular}{|c|c|c|c|}
\hline Item & $\mathrm{n}$ & Mean & SD \\
\hline Intellectual challenges and stimulation & 225 & 3.32 & 1.05 \\
\hline Desire to be a teacher & 229 & 3.10 & 1.17 \\
\hline Interest in science, new discovery, exploration & 224 & 2.93 & 1.12 \\
\hline Variety of work activities available in academics & 240 & 2.93 & 1.30 \\
\hline Opportunity for regular interaction with other faculty dentists & 239 & 2.86 & 1.26 \\
\hline Varied life and professional activities & 224 & 2.83 & 1.32 \\
\hline Opportunity to always be on cutting edge & 218 & 2.75 & 1.31 \\
\hline Opportunity to influence a field of study and shape a profession & 221 & 2.70 & 1.23 \\
\hline University collegial environment & 238 & 2.66 & 1.18 \\
\hline Opportunity for interaction with university/medical center faculty & 236 & 2.46 & 1.31 \\
\hline Faculty role model at your dental school/advanced education program & 222 & 2.43 & 1.65 \\
\hline Opportunity to collaborate on projects of national and international importance & 221 & 2.42 & 1.43 \\
\hline Experiences during advanced training & 226 & 2.35 & 1.51 \\
\hline Opportunity to do research & 234 & 2.30 & 1.67 \\
\hline Chance to develop a national/international network of colleagues and friends & 237 & 2.25 & 1.42 \\
\hline Influence of faculty mentor & 221 & 2.22 & 1.55 \\
\hline Success in dental school & 225 & 2.22 & 1.64 \\
\hline Desire for stable source of income and benefits & 227 & 2.09 & 1.89 \\
\hline Opportunities for advancement & 224 & 2.00 & 1.85 \\
\hline Research training opportunities & 223 & 1.93 & 1.71 \\
\hline Research training experiences & 219 & 1.88 & 1.79 \\
\hline Freedom of movement & 230 & 1.45 & 1.96 \\
\hline Work schedule of dental faculty & 233 & 1.40 & 2.18 \\
\hline Experiences in private practice & 207 & 1.23 & 1.94 \\
\hline Aspirations to be a dental school or university administrator & 231 & 1.21 & 1.67 \\
\hline Convenience & 212 & 1.19 & 1.72 \\
\hline Access to the tenure system & 225 & 1.15 & 1.88 \\
\hline Perceptions of private practice & 216 & 0.71 & 2.13 \\
\hline Military service experiences & 186 & 0.70 & 1.52 \\
\hline Influence of parents and relatives & 221 & 0.62 & 1.58 \\
\hline Obligation to do research & 227 & 0.15 & 2.26 \\
\hline Change by universities to an emphasis on nontenure-track positions & 215 & 0.04 & 2.15 \\
\hline Time required for preparation for academic career & 210 & -0.38 & 2.30 \\
\hline Pressure to generate income for university & 225 & -0.86 & 1.59 \\
\hline Level of indebtedness & 214 & -0.94 & 2.04 \\
\hline Income level of dental faculty & 236 & -1.15 & 2.20 \\
\hline Income differential compared to private practice & 222 & -1.77 & 1.87 \\
\hline
\end{tabular}

\section{Relationships Between Demographic Variables and Responses to Categories of Correlated Survey Items}

Some of the above relationships can also be seen when the items grouped by factors analysis is considered the independent variable. For example, as shown in Figure 2, income and indebtedness factors were a more negative influence for those with fewer years in private practice than for those with significant private practice experience $\left(\mathrm{R}^{2}=.06, p=\right.$ .0001). A complex relationship was seen when age was examined (Figure 3). Younger faculty with less than one year of service considered income and indebtedness to be a more negative influence than did older faculty. For faculty with one to four years of service, there was no effect of age on the influence of income and indebtedness on the decision to enter academics; it was a negative factor regardless of age.
Analysis of relationships between research items and demographic variables revealed two interesting relationships. First, the data indicated that nonU.S. citizens expressed a more positive influence of research on their decision to enter academics than did U.S. citizens ( $p=.0097$ ) (Figure 4). Secondly, there was a relationship between the number of years of postgraduate training and the importance of research as a factor in choosing academic careers (Figure 5). New faculty members with more years of postgraduate training reported that both research opportunities and the obligation of faculty to do research were positive influences on their decision to enter academic dentistry.

It was found that there was a significant relationship between years of private practice and teaching and scholarship considerations, but there was a significant interaction $(p=.0005)$. The interaction indicated that for faculty with $>1$ year of service there was a significant decrease in score with increased 
Table 5. Stepwise analyses of relationships of demographic factors to survey items as considerations in choosing academic careers ${ }^{\mathrm{a}}$

\begin{tabular}{|c|c|c|}
\hline Age & $\begin{array}{l}\text { Signif. } \\
\text { (p) }\end{array}$ & $\begin{array}{l}\text { Slope } \\
(+ \text { or }-)\end{array}$ \\
\hline $\begin{array}{l}\text { Income differential compared to } \\
\text { private practice }\end{array}$ & .0166 & - \\
\hline Intellectual challenges and stimulation & .0171 & - \\
\hline $\begin{array}{l}\text { Time required for preparation for a } \\
\text { cademic career }\end{array}$ & .0381 & - \\
\hline \multicolumn{3}{|l|}{ Years in Private Practice } \\
\hline $\begin{array}{l}\text { Pressure to generate income for } \\
\text { university }\end{array}$ & .0001 & + \\
\hline Income level of dental faculty & .0015 & + \\
\hline Level of indebtedness & .0049 & + \\
\hline $\begin{array}{l}\text { Income differential compared to private } \\
\text { practice }\end{array}$ & .0093 & + \\
\hline $\begin{array}{l}\text { Time required for preparation for } \\
\text { academic career }\end{array}$ & .0165 & + \\
\hline Desire to be a teacher & .0186 & - \\
\hline Opportunities for advancement & .0253 & - \\
\hline Military service experiences & .0461 & + \\
\hline Freedom of movement & .0408 & + \\
\hline \multicolumn{3}{|l|}{ Years in Military } \\
\hline Varied life and professional activities & .0044 & - \\
\hline Income level of dental faculty & .0113 & + \\
\hline $\begin{array}{l}\text { Income differential compared to } \\
\text { private practice }\end{array}$ & .0196 & + \\
\hline \multicolumn{3}{|l|}{ Foreign vs. U.S. Citizen } \\
\hline $\begin{array}{l}\text { Opportunity for interaction with uni- } \\
\text { versity/medical center faculty }\end{array}$ & .0039 & - \\
\hline Research training opportunities & .0045 & + \\
\hline $\begin{array}{l}\text { Aspirations to be a dental school or } \\
\text { university administrator }\end{array}$ & .0188 & - \\
\hline \multicolumn{3}{|l|}{ Tenure Track vs. Nontenure Track } \\
\hline Influence of parents and relatives & .0262 & + \\
\hline Income level of dental faculty & .0387 & + \\
\hline \multicolumn{3}{|l|}{ New vs. Non-new Faculty } \\
\hline Desire to be a teacher & .0234 & - \\
\hline Experiences in private practice & .0326 & - \\
\hline
\end{tabular}

${ }^{a}$ Factors listed are those with for which $\mathrm{p}<.05$.

years in private practice $(\mathrm{p}<.0001)$, but within faculty members with $\leq 1$ year of service, there was no relationship (Figure 6).

\section{Discussion}

Overall, the results of this survey indicate that factors that relate to the intellectual and scientific challenge and stimulation, the lifestyle of academicians, and interest in teaching are the most positive influences on the decision process in choosing aca- demic dentistry as a career. Other important positive considerations for those entering academics are mentorship, role models, and research and research training opportunities. The most important negative factors identified by new dental faculty related to income and indebtedness. These results are not surprising and reinforce conventional wisdom. Those choosing academics are seeking intellectual stimulation that they perceive is available in the dental school environment, and they wish to educate others. This result is similar to that in a recent study by Kula and colleagues, ${ }^{3}$ who observed that orthodontic teaching faculty listed intellectual stimulation, students interaction, desire to contribute to the profession, and collegiality as the major factors influencing their decisions to enter academics. On the other hand, and particularly for younger dentists, issues surrounding their student loan indebtedness and perceptions about lower income levels of dental faculty are important and likely disturbing factors. These factors have been identified by a number of authors as major influences on the decision to choose academics as a career. ${ }^{1-7}$ In view of the fact that those responding to the survey were the select group of dentists who chose academics as a career, it is safe to surmise that these negative factors are amongst those that deter other dentists from choosing academics.

The intent of this survey was to identify factors that were positive influences on the decision to enter academics. Hopefully, these data can be used by dental schools to develop strategies to attract new faculty in the future. Since U.S. dental schools are experiencing difficulty recruiting new faculty, it might be the case that current faculty are placing insufficient emphasis on the positive aspects of academic dentistry. Though this may not have been necessary in the past, the apparently negative effect of student debt and income differential compared to the private sector have made recruitment efforts directed at current predoctoral and advanced education dental students within our own institutions essential. The influence of role models and mentors for this group of respondents was important and positive, and this interaction would appear to be the one most likely to influence dentists' perceptions of the benefits of academic careers. Recruitment of new faculty will likely be enhanced if faculty mentors portray the positive aspects of academic careers as a fair balance to the negative concerns of dental graduates regarding economic factors. 


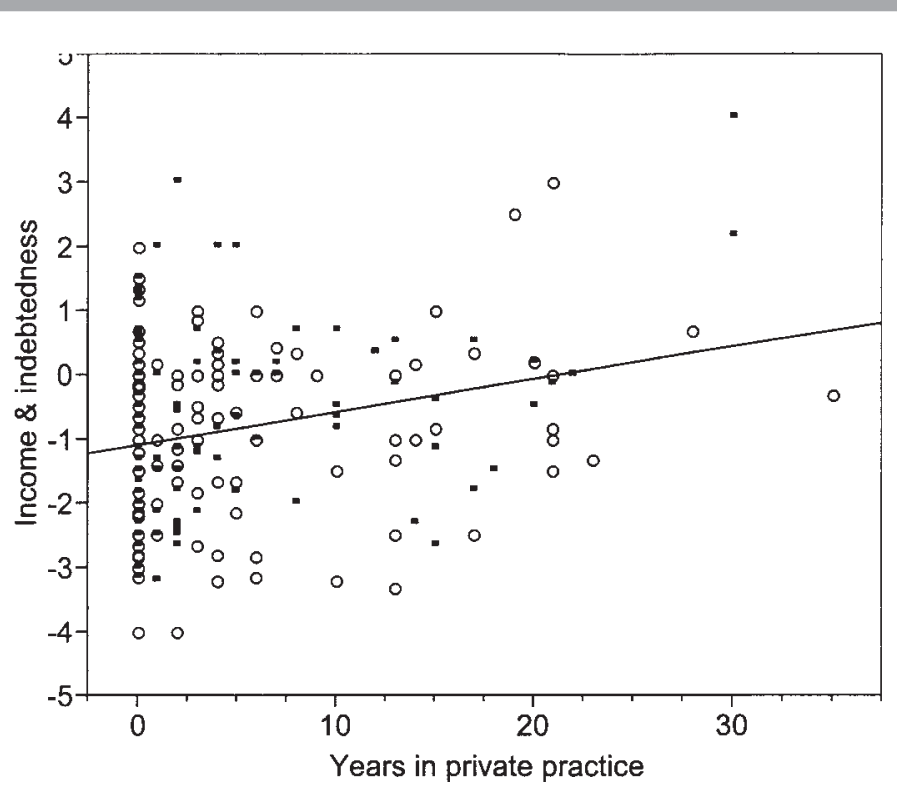

Figure 2. Influence of years in private practice on and indebtedness items

Data for all respondents are shown. Open symbols represent responses from faculty with $\leq 1$ year of service; closed symbols represent responses from faculty with one to four years of service. For all individuals surveyed, $\mathrm{R}^{2}=.06, p=.0001$.

The characteristics of the respondents to this survey may represent new or continuing trends in the characteristics of individuals choosing to enter academic dentistry. Kennedy and Hunt ${ }^{4}$ reported that

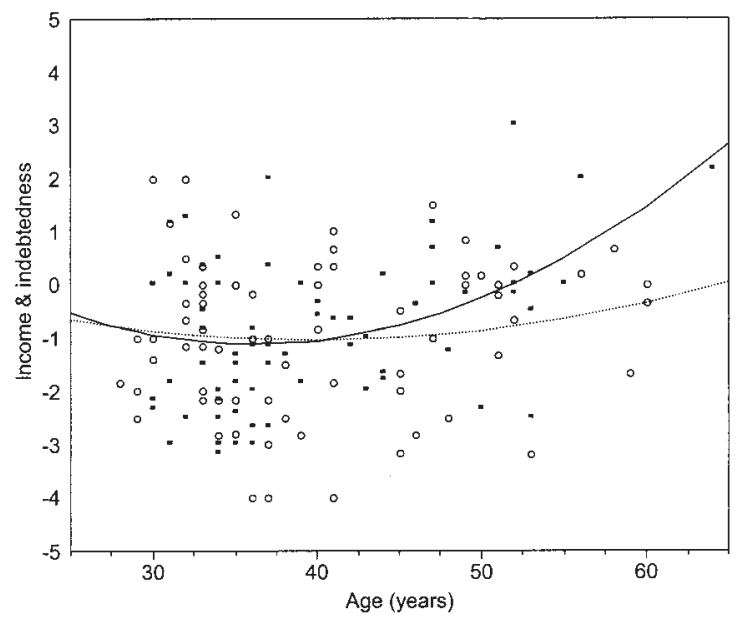

Figure 3. Influence of age on income and indebtedness items

Solid line represents responses from faculty with $\leq 1$ year of service $\left(R^{2}=\right.$ $.15, p=.0003)$; dotted line represents responses from faculty with one to four years of service $\left(\mathrm{R}^{2}=.08, p=.6\right)$.
18 percent of full-time clinical faculty in $1995 / 96$ were female, while we found that 31.7 percent of new faculty were female. Apparently, there is still a trend for increasing proportions of the faculty to be female. Secondly, in 1997, 61.3 percent of faculty were in tenure-track positions, while only 52.9 percent of new faculty are currently in tenure tracks, representing a possible trend towards non-tenurable positions. Furthermore, as seen in Table 4, access to the tenure system is not considered to be as important a consideration for choosing academic careers as are many other factors. New faculty in U.S. dental schools also comprise a diverse group of individuals with respect to professional experience and training. More than half of the new full-time faculty have previous experience in private practice, averaging about eight years, and one-fifth have military experience averaging about sixteen years. The bimodal age distribution of new faculty shown in Figure 1 is likely a reflection of the mixture of individuals choosing academics as a first career with those embarking upon second careers. In some respects, these two groups expressed different factors as considerations in choosing academics, as shown in Figures 2, 3, and 4. As one might expect, those with previous military and practice experience, as well as those who are older, view the income and indebtedness issues as less negative influences on their career decision.

Analyses of demographic data indicate that some groups of dentists were differently motivated to enter academics and had concerns specific to that group. Rice and colleagues ${ }^{5}$ reported that dentists leave the private practice of dentistry mainly due to concerns about finances and regulatory issues. Such dentists choose a number of career paths, among which is academics. In the present study, former private practitioners with more years of experience were significantly less concerned about economic issues (Table 5) and considered freedom of movement to be a positive consideration. However, former private practitioners with more than ten years of experience reported that the desire to teach was less of a positive factor than those with less private prac- 


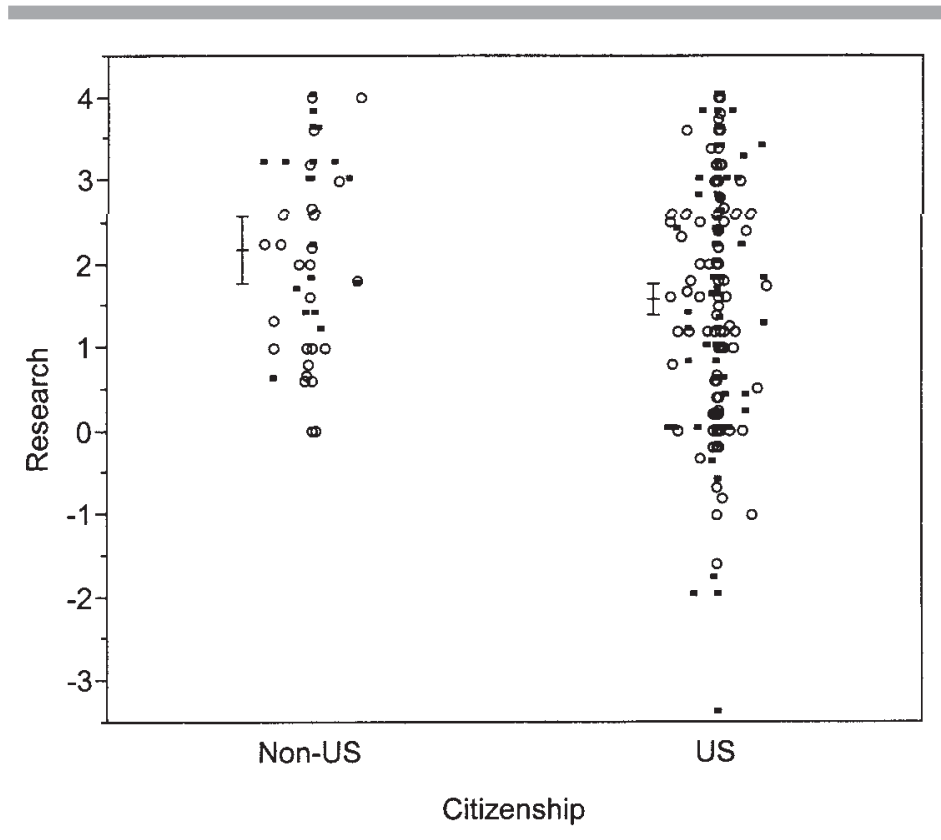

Figure 4. Influence of citizenship on research items

Open symbols represent responses from faculty with $\leq 1$ year of service; closed symbols represent responses from faculty with one to four years of service.

tice experience. Further analysis of this unexpected response revealed that, for new faculty ( $\leq$ 1year), teaching and scholarship considerations were posi-

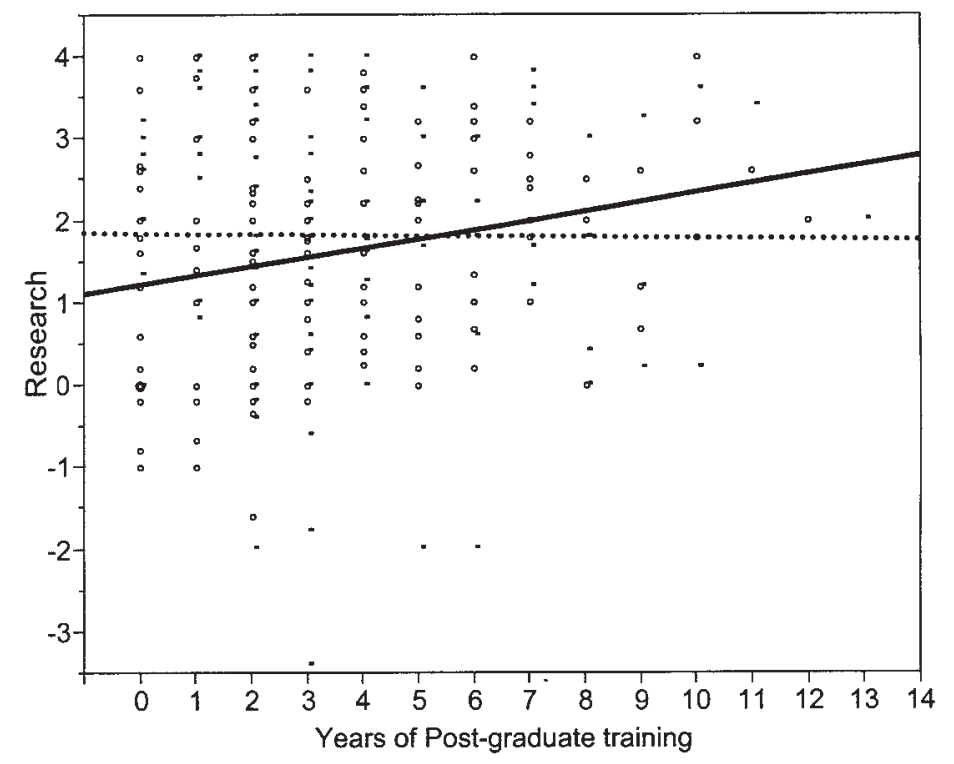

Figure 5. Influence of postgraduate training on research items.

Solid line represents responses from faculty with $\leq 1$ year of service $\left(\mathrm{R}^{2}=.54, p=.0059\right)$; dotted line represents responses from faculty with one to four years of service $\left(R^{2}=0.0, p=.9\right)$. tive without regard to the number of years the faculty had been in practice. Yet, faculty with one to four years of academic service and with more than ten years of practice experience viewed this factor increasingly negatively. Perhaps the initial few years of academic experience of former career practitioners alters their perception of the teaching and intellectual factors, thus changing their perception of the influence of these factors on their decision to enter academics. These faculty may be reporting on their current disillusionment rather than their considerations in initially choosing to enter academics. If this is so, it may be that dental schools need to place more emphasis on career development of former practitioners when they enter academics so as to enhance their satisfaction with their second career.

Research at dental schools, and the training and recruitment of dental researchers, has been a special concern within the larger issue of dental faculty recruitment. The results of this survey indicated that two of the demographic factors examined were related to consideration of research as a factor in choosing to enter academics. First, non-U.S. citizens reported significantly more positive scores, indicating that research activities and opportunities were a more positive consideration for this group (Figure 4). This result could be a reflection of the fact that U.S. dental schools may be recruiting a substantial number of researchers from other countries because there are few individuals being currently trained in the United States for careers in dental research. There was also a positive correlation between the number of years of postgraduate training and the research factors. This relationship may simply reflect the fact that bona fide research training requires extra years of preparation and that those with more postgraduate training have devoted part of this time to research training. Since 87 percent of new faculty have postgraduate training of some sort, averaging about four years (Table 1), it is not postgraduate training per se but rather the extra years of training that promote research as a positive factor in choosing academics. 


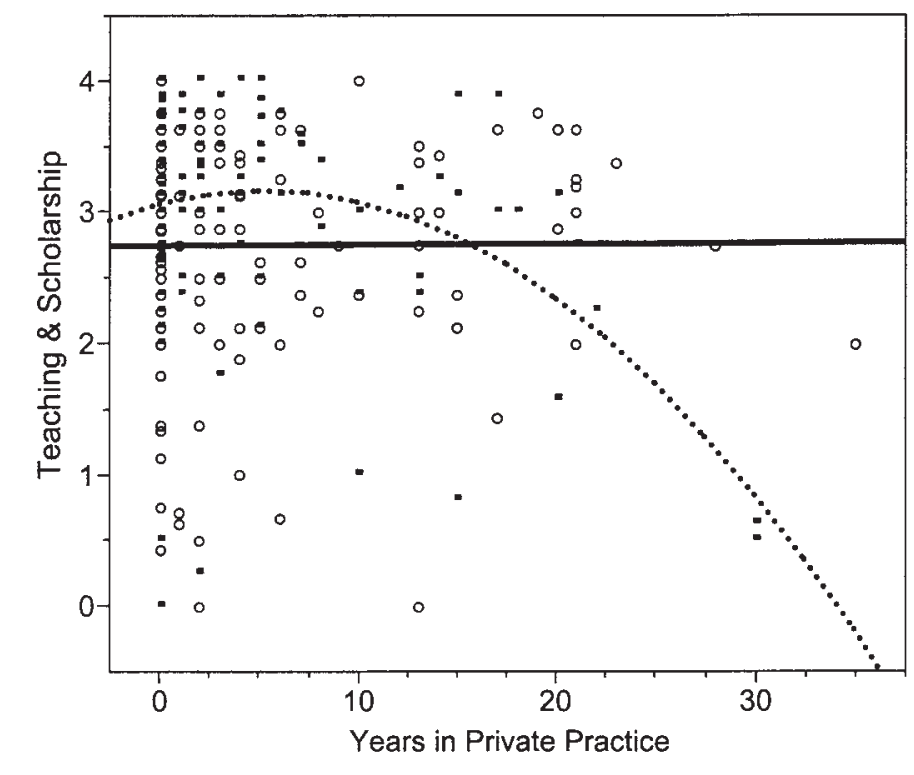

Figure 6. Influence of years in private practice and years as faculty member on teaching and scholarship items

Solid line represents responses from faculty with $\leq 1$ year of service $\left(R^{2}=\right.$ $0.0, p=.9$ ); dotted line represents responses from faculty with one to four years of service $\left(\mathrm{R}^{2}=.17 \%, p=.0001\right)$.

Kennedy and Hunt ${ }^{4}$ suggest that major deterrents to careers in academic dentistry include differences in compensation between academic dentists and practitioners, the additional time and resources for preparation for such a career, and decreased potential to achieve tenure. By and large, the select individuals who chose academic careers express similar concerns, with the exception of the concern that they will have difficulty becoming tenured. The issue of tenure was not expressed as a major concern, perhaps because the survey did not adequately probe this issue or because the group responding to the survey did not see tenure as being a major impediment. Approximately half of those in the sample were in tenure-track positions. Since many institutions are increasingly utilizing nontenurable appointments for a significant proportion of the faculty, this item may not be a major consideration for this group of individuals. However, these data do not address the question of whether graduate dentists as a group see tenure issues as an important impediment.
In summary, the data support the assumption that income relative to private practice opportunities and indebtedness of young dentists are influential factors in choosing career paths in dentistry. This is seen even among select individuals who have chosen to enter academia despite these obstacles, further implicating these factors as those requiring immediate attention during the next several years. Additionally, those individuals who choose academics apparently do so for the traditional reasons of interest in scholarship and teaching with mentoring and research experiences as important supporting factors. The implications of these results are that fostering of the positive aspects of academics is imperative in dental schools. Mentoring of individuals who lean toward scholarship and research, along with development of strategies to minimize the financial barriers that mitigate against consideration of academic careers, is essential in the very near future to ensure that sufficient faculty are available in dental schools. Additionally, the important cadre of individuals who choose academic dentistry as a second career must be offered sufficient developmental programs to make academics as fulfilling a career as they initially envisioned.

\section{REFERENCES}

1. American Association of Dental Schools. Report of the AADS president's task force on future dental school faculty. Washington, DC: AADS, 1999:3-11.

2. Haden NK, et al., Dental school faculty shortages increase: an update on future dental school faculty. J Dent Educ 2000;64:666-82.

3. Kula, K, et al., Reasons that orthodontic faculty teach and consider leaving teaching. J Dent Educ 2000;64:755-762.

4. Kennedy JE, Hunt RJ. Meeting the demand for future dental faculty. In: Leadership for the future: the dental school in the university. Washington, DC: American Association of Dental Schools, 1998.

5. Rice $\mathrm{CD}$, et al. Career changers: dentists who choose to leave private practice. J Am Coll Dent 1997;64:20-6.

6. Laskin DM. Factors influencing oral and maxillofacial surgeons to select or leave academic careers. J Oral Maxillofac Surg 1994;52:174-6.

7. Feigal RJ. Producing the next generation of professional educators in pediatric dentistry. Pediatr Dent 1997;19:18992. 